ORIGINAL ARTICLE

\title{
BIBLIOMETRIC MAPPING OF PAPERS ON GEOGRAPHICAL INFORMATION SYSTEMS (2007-2016)
}

Alexandre Vastella Ferreira de Melo ${ }^{1}$ - ORCID: 0000-0003-2965-7375

Alfredo Pereira de Queiroz ${ }^{1}$ - ORCID: 0000-0003-4038-4953

E-mail: alexandrevastella@gmail.com; aqueiroz@usp.br

${ }^{1}$ Universidade de São Paulo, Departamento de Geografia, São Paulo, São Paulo, Brasil

Received in 03 ${ }^{\text {rd }}$ June 2018

Accepted in 05 $5^{\text {th }}$ January 2019

\begin{abstract}
:
The amount of researchers and scientific papers rapidly grows, annually. The metrics to analyze the quality and quantity of these publications have consolidated in the academic world. A bibliometric mapping of scientific papers on Geographic Information Systems (GIS) published between 2007 and 2016 was carried out. The sample analyzed 2,053 papers, extracted from twenty journals of the Web of Science Core Collection platform. The following were evaluated: total number of publications, production by area of knowledge and by country, authors, periodicals and the most cited words. The results shows that 2012 and 2013 were the most productive periods, and that the annual growth rate of publication was $1.8 \%$. The most significant academic areas were Geography, Computer Science, Physical Geography, and Environmental Sciences/Ecology. The three major publishing clusters were North America, Western Europe, and Eastern Asia. The International Journal of Geographic Information Science was considered the most important journal. The most relevant topics were cellular automata, relationship between GIS and users, integration of GIS with remote sensing, different land use classification methods, and critical reflections on technologies and GIS.
\end{abstract}

Keywords: Bibliometric mapping; papers; Spatial Analysis

How to cite this article: MELO, A.V. F. and QUEIROZ, A. P. Bibliometric Mapping of Papers on Geographical Information Systems (2007-2016). Bulletin of Geodetic Sciences, 25(3): e20190015, 2019. 


\section{Introduction}

Geographic research has evolved from data-scarce to a data-rich/big-data environment. New techniques have emerged to analyze large volumes of data, with environmental and societal aspects. Created by millions of sensors this data comes from remote sensing images, GPS coordinates, maps, blogs, videos, audios, photos, messages, among others (Egenhofer et al. 2016).

Geographic Information Systems (GIS) are computer systems used for collecting, storing, processing, and displaying georeferenced information (Burrough 1998). In the past three decades, the importance of GIS has increased considerably because of the development of hardware, software, and data connectivity (Peng and Tsou 2003; Goodchild, Yuan and Cova 2007). Getis (2008) considers that the methods and concepts of GIS has matured since the 1990s. These have become fundamental for different areas of research, such as ecology, epidemiology, sociology, urban planning, geology and environmental studies.

According to Huggett (2013), the growth of the number of researchers and scientific papers has increased the importance of publication metrics to evaluate scientific trends. Simultaneously, computational and data storage advances have improved the accessibility and ease of use of bibliometric measures. Bibliometrics is defined as the application of mathematics and statistical methods to evaluate books and other means of communication (Pritchard 1969). Bibliometric maps are considered graphical representations of bibliometry (van Eck, Waltman, Dekker and Berg 2010).

Since the early sixties, bibliometric procedures have been used to analyze geographic publications. Bunge (1961) evaluated three journals (Annals of the Association of American Geographers, Geographical Review, and Economic Geography) from 1958 to 1960 to identify the schools of thought in geography. Stoddart (1967) investigated the growth of geography as a scientific activity, the productivity of geographers, and internal and external relations in geographic work. Gatrell and Smith (1984) analyzed the network of interrelationships of 22 geographic journals from 19701972 and 1980-1982 by calculating the frequency with which papers published in one journal cited papers published in another journal. Whitehand (1984) examined the impact of geographical journals from 1978 to 1982. Wrigley and Matthews (1986) evaluated the characteristics of citations of scientific papers and geography books.

Robinson and Poston (2006) determined the citation patterns of 1,555 references from the journals Annals of the Association of American Geographers, Applied Geography, Cartographic Journal, Economic Geography, and Geographical Analysis starting in 2000. Tian, Wen and Hong (2008) analyzed the scientific production on GIS from 1997 to 2006 and observed that the number of journals and publishing countries was increased considerably, with an annual growth rate of $11.5 \%$ and publication peaks in 2000 and 2003. Moreover, these authors estimated that the number of scientific papers on GIS published in 2012 would be two times higher than in 2006.

Xuemei, Mingguo and Zhiqiang (2014) have reported that bibliometry is often used to map geographic science. Wei, Grubesic and Bishop (2015) mapped the GIS literature from 2002 to 2013, and Liu et al. (2016) extended the analysis period from 1961 to 2010. Li, Liu, Guo and Yu (2016) used bibliometrics to analyze the evolution of GIS in China. Li et al. (2017) used bibliometrics to analyze the evolution of geo-ontological thinking. 
The aim of this study is to perform the bibliometric mapping of scientific papers on GIS published from 2007 to 2016. Data on the total publications, production by area of knowledge and country, authors, journals, and the most cited words from the top 20 journals, extracted from the Web of Science Core Collection platform (WoS), were analyzed. It seeks to answer questions such as: Does the growing trend of the use of GIS in scientific research continue? In what areas of knowledge is GIS most used?

\section{Method}

Bibliometric mapping is the product of a quantitative method that represents the bibliographic data of scientific literature visually (van Eck 2011; Waltman, van Eck and Noyons 2010; Morris and Martens 2009). This visual representation is a map although it has characteristics of a graph. The maps contain two fundamental attributes, distance which is inversely proportional to the connection between the objects and indicates the proximity between two or more elements. For instance, the closer two authors are represented on the map, the greater is the degree of connection of these authors in the scientific community. Secondly, size of the symbol indicates its relevance in the represented universe. Despite the lack of cartographic scale and correlation with the terrestrial surface, bibliometric maps show the centrality and marginality of the universe represented (van Eck 2011; van Eck, Waltman, Dekker, and Berg 2010; van Eck and Waltman 2007).

The papers and their metadata were extracted from the Web Science Core Collection platform (WoS). The selection of the international journals was based on the studies by Scarletto (2014) and Caron, Roche, Goyer and Jaton (2008), who classified the main journals on GIS. Twenty journals common to both studies were selected. Table 1 represents the selected journals and also the position of the search rankings of these authors. In these 20 journals, the terms "Geographic* Information System*," "GIS," and "GIScience" were searched in the title, abstract, or keywords of WoS database. The analyzed sample totaled 2,053 scientific papers.

Excel software was used to edit and manage tables. ArcGis 10.1, to create the world map. The VosViewer was used to elaborate bibliometric maps (van Eck and Waltman 2010) and, CitnetExplorer to represent the citation network of sample papers according to time (van Eck and Waltman 2014). 
Table 1: Journals selected for the study (ranking position of the authors research)

\begin{tabular}{|c|c|c|}
\hline SELECTED JOURNALS & Caron et al. (2008) & Scarletto (2014) \\
\hline International Journal of Geographic Information Science & 1 & 1 \\
\hline International Journal of Remote Sensing & 2 & 17 \\
\hline Photogrammetric Engineering \& Remote Sensing (PE\&RS) & 3 & 6 \\
\hline Computers and Geosciences & 4 & 14 \\
\hline Transactions in GIS & 5 & 9 \\
\hline Geolnformatica & 6 & 19 \\
\hline Cartography and Geographic Information Sciences & 8 & 3 \\
\hline Environment and Planning $\mathrm{A}$ & 9 & 13 \\
\hline Remote Sensing of Environment & 11 & 29 \\
\hline Computers, Environments and Urban Systems & 12 & 5 \\
\hline Annals of the Association of American Geographers & 13 & 2 \\
\hline URISA Journal & 14 & 37 \\
\hline Environment and Planning $B$ & 15 & 4 \\
\hline Landscape Ecology & 16 & 33 \\
\hline Cartographica & 17 & 8 \\
\hline Professional Geographer & 22 & 11 \\
\hline Transactions of the Institute of British Geographers & 23 & 20 \\
\hline Progress in Human Geography & 25 & 10 \\
\hline Cartographic Journal & 29 & 18 \\
\hline Geographical Analysis & 43 & 7 \\
\hline
\end{tabular}

\section{Results and Discussion}

The most productive period for the number of publications, was said to have been in 2012 and 2013. Others such as, areas of knowledge and publication peaks were most productive in 2009 and 2012 (Figure 1). 


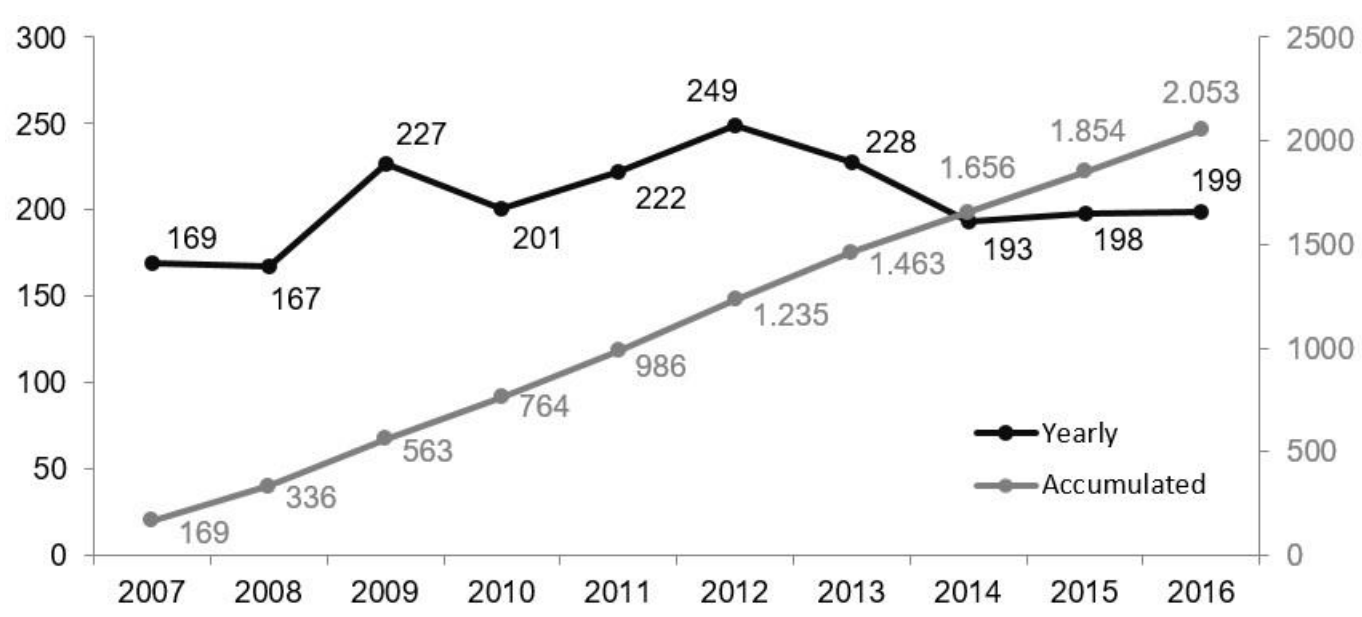

Figure 1: Number of publications on GIS per year (2007-2016).

From 2007 to 2016, the annual growth rate of the publication in selected journals was $1.8 \%$. This value corroborates the percentage of increase found by Tian, Wen and Hong (2008), although their sample was much larger and included the periods 1997-2006 (9,109 papers from 1,918 journals).

GIS production by academic area is shown in Figure 2. The areas with the highest scientific production were Geography, Computer Science, and Physical Geography. Production was increased in the areas of Environmental Sciences/Ecology and Engineering, from 2014 to 2015. The scientific production in the area of Environmental Sciences was similar to that of Geology and Information Science, and the average yearly production in the three areas was 30 to 50 publications.

The academic areas were defined by WoS, which is declaratory and multiple choice information filled out by the author during the submission process. Each paper may be associated with one or more WoS areas of knowledge. In this database, Geography is part of the group of Social Sciences and Physical Geography belongs to Physical Sciences.

These results agree to a certain extent with those obtained by Liu et al. (2016), who evaluated 17,451 papers from 2,310 journals in 1961-2010. These authors observed that the seven most productive areas of knowledge from 1991 to 2010 were Environmental Sciences, Multidisciplinary Geosciences, Ecology, Physical Geography, Water Resources, Geography, and Remote Sensing. In addition to the difference in order, the areas Multidisciplinary Geosciences and Water Resources were absent. This discrepancy may be due to differences in the sampling strategy used in these studies. 


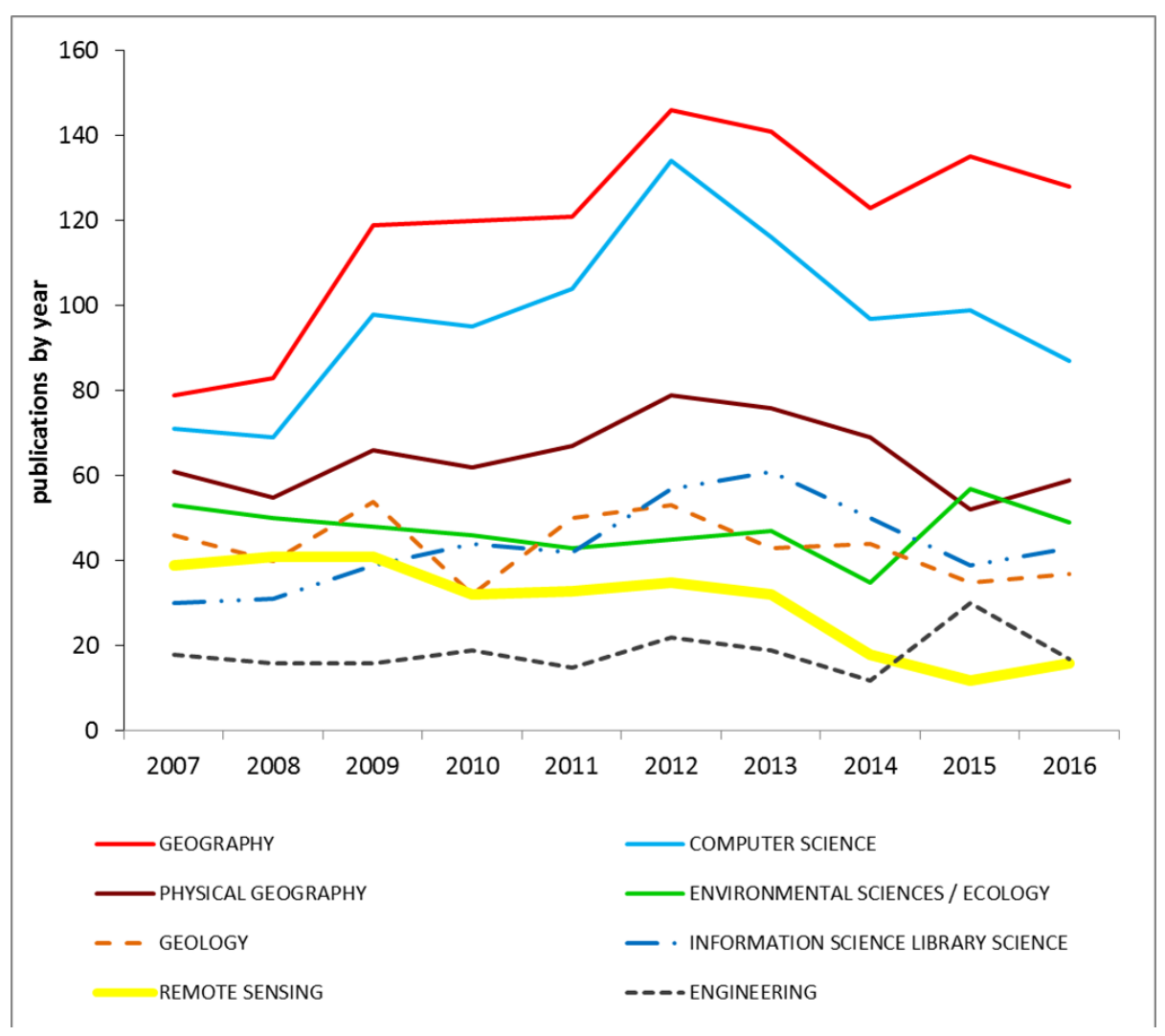

Figure 2: Annual publications on GIS by area of knowledge (2007-2016).

From a spatial point of view, the most productive GIS research centers were concentrated in the northern hemisphere (Figure 3). Most papers (61.7\%) were published in English-speaking countries (United States, Canada, United Kingdom, Australia, and South Africa). Among the 2,053 papers in the sample, the United States was the most important publishing country, with 821 publications. When combined with Canada (140), North America accounted for $46.8 \%$ of the total. Western Europe amounted to 26.8\% of total production, represented by United Kingdom (223), Netherlands (84), Germany (83), Italy (81) Spain (79). Asia accounted for $20.8 \%$ of the total production. China published 304 papers and was the second most productive country, followed by Japan (42), India (41), and South Korea (41). In Oceania, Australia published 77 papers. In South America, the most productive country was Brazil, with 24 papers. In Africa, Egypt and South Africa published 10 and 5 papers, respectively, in the evaluated period.

The world map shown in Figure 3 is very similar to that developed by Liu et al. (2016) and highlights three main clusters: North America, Western Europe, and Eastern Asia. From this perspective, it is considered that the supremacy in the publication of papers remained unchanged. 


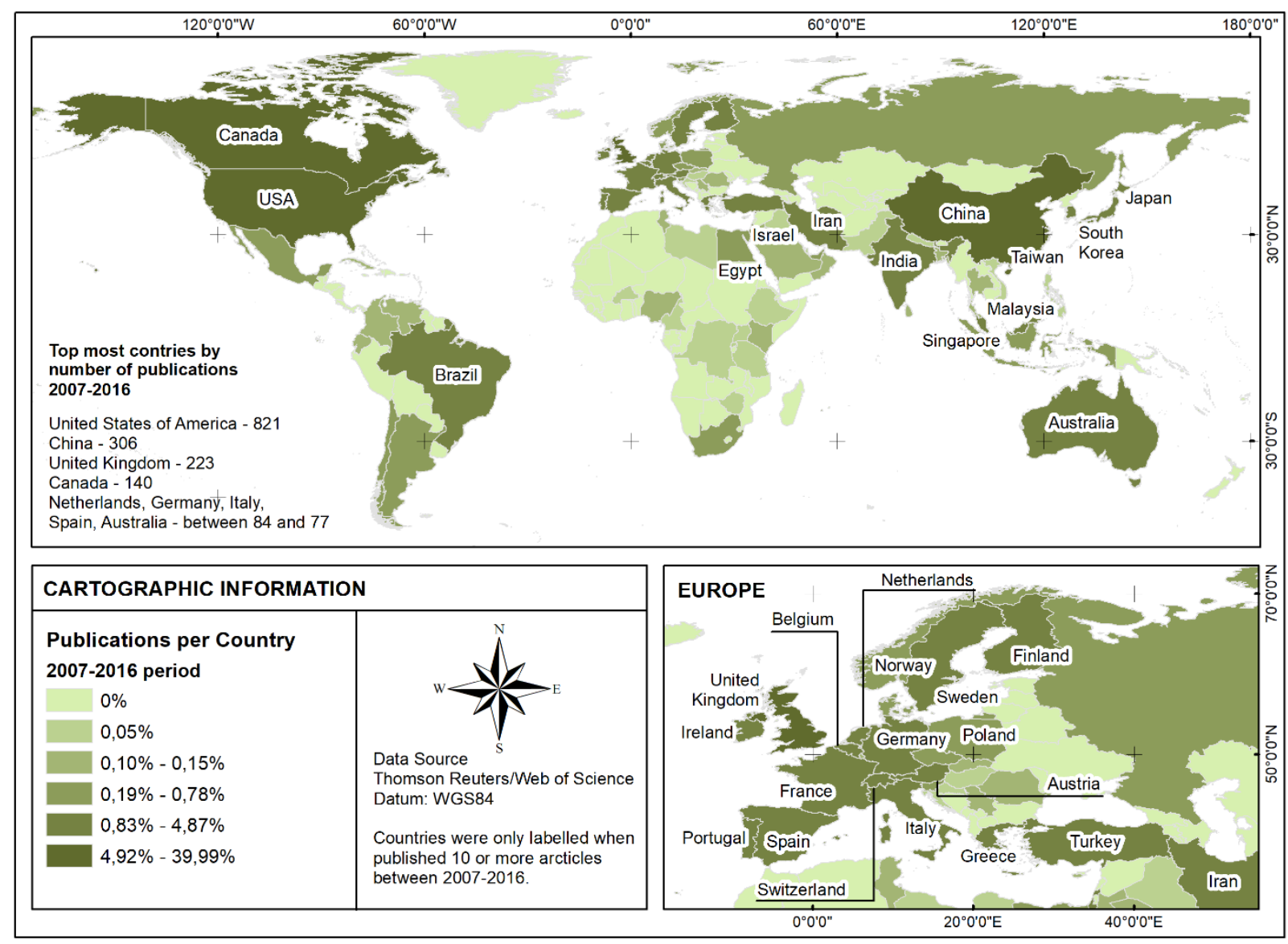

Figure 3: Percentage of publications on GIS by country (2007-2016).

The most cited authors are shown in Figure 4. Michael Frank Goodchild, a professor at the University of Santa Barbara (California, USA), has a total of 638 citations. Mei-Po Kwan, from the University of Hong Kong, had 311 citations (currently at the University of Illinois). Michael Frank Goodchild and Mei-Po Kwan are the most important references in their respective clusters (North America and Eastern Asia, respectively).

In this figure, the authors are represented by proportional circles and indicate their relevance in comparison to the represented universe. The greater the lines thickness, the stronger the connection between the authors, while the colors selectively show the groupings by connection levels. Goodchild appears with the greatest symbol, being the most cited author among the selected journals on GIS between 2007-2016 (638 citations). The proximity indicates the degree of similarity between the key words of the authors' papers and, the colors, group that affinity.

These results indicate that geography plays a central role in the formation and/or academic contribution of the most prominent authors on GIS. Examples of graduates in geography include Sarah Elwood, Harvey Miller, Stan Openshaw, Alan MacEachren, Nadine Schuurman, Alexander Fotheringham, Waldo Tobler, and Donna Peuquet. Geography postgraduates include physicist Michael Goodchild, geologist Xingong Li, economist and philosopher Roger White, mathematician Alan T. Murray, and economist Piotr Jankowski. 


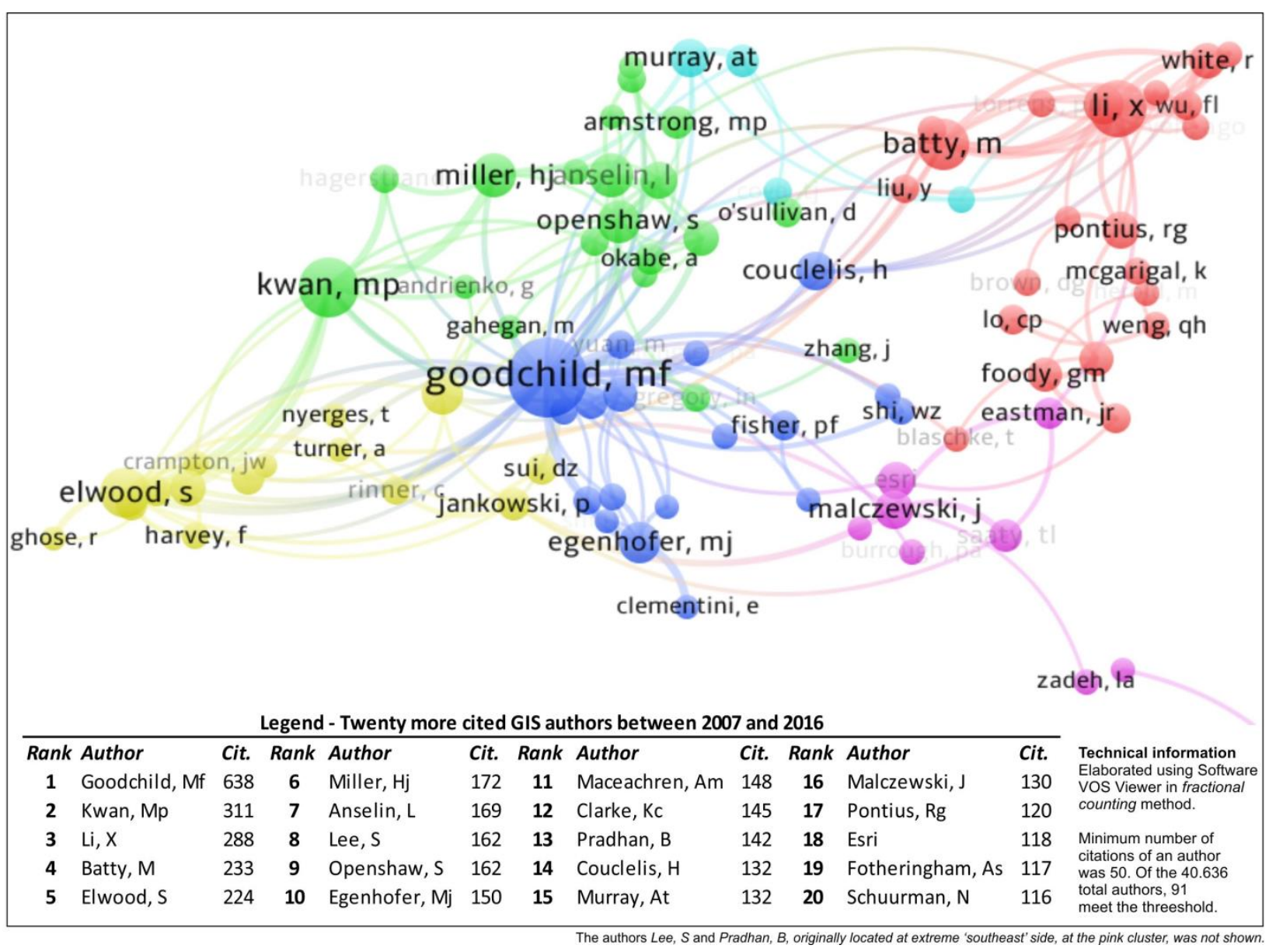

Figure 4: Publications on GIS by author (2007-2016).

The most cited journals are shown in Figure 5. The International Journal of Geographic Information Science is the most influential journal on GIS, considering 2,811 citations and also the ranking of Caron, Roche, Goyer and Jaton (2008) and Scarletto (2014). The same cluster (in yellow) includes journals Transactions in GIS and Lecture Notes in Computer Science, indicating the interface between geography and computing. The green cluster contains journals on remote sensing, including the International Journal of Remote Sensing, Remote Sensing of Environment, and Photogrammetric Engineering and Remote Sensing. The red cluster comprises journals that are more directly related to geography and urban studies, including Annals of the Association of American Geographers, Geojournal, and Environment and Planning B. The blue cluster contains primarily journals on urban and environmental planning, including Landscape Ecology, Landscape and Urban Planning, and Science.

Among the obtained results, this classification differed the most from the classification of Liu et al. (2016). Among the 20 journals, although the first four were the same, only six were common to the two classifications: International Journal of Geographic Information Science, International Journal of Remote Sensing, Photogrammetric Engineering \& Remote Sensing, Computers, and Geosciences, Environment and Planning B., and Landscape Ecology. 


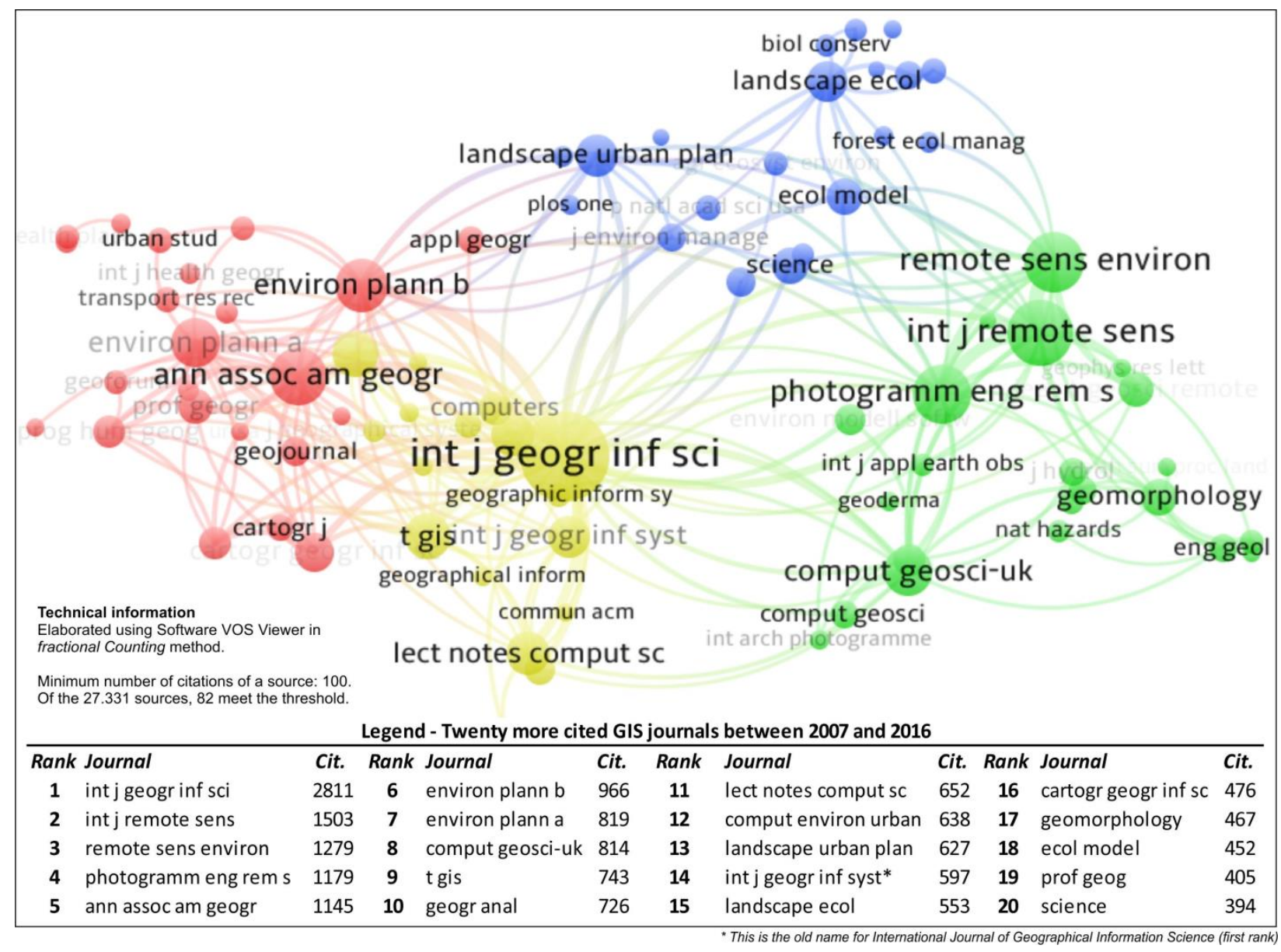

Figure 5: Main journals on GIS (2007-2016).

Figure 6 was constructed using an interpolation Kernel function and shows the most cited words in the abstract, title, and keywords of the retrieved papers. In this representation, word cooccurrence was used. It is a technique of content analysis that uses the words of documents to establish relationships and build a conceptual framework of the domain (Callon, Courtial, Turner, and Bauin 1983). In addition to the term "GIS" used in sample selection, other common terms were used, such as "data," "model," "analysis," "method," "area," and "map."

This pattern seems to confirm the Zipf Law (Law of Least Effort), which considers that language tends to be used on the basis of the least effort to save words. The most used words tend to have the strongest correlation with the study topic (Harremoes and Topsoe 2005). 


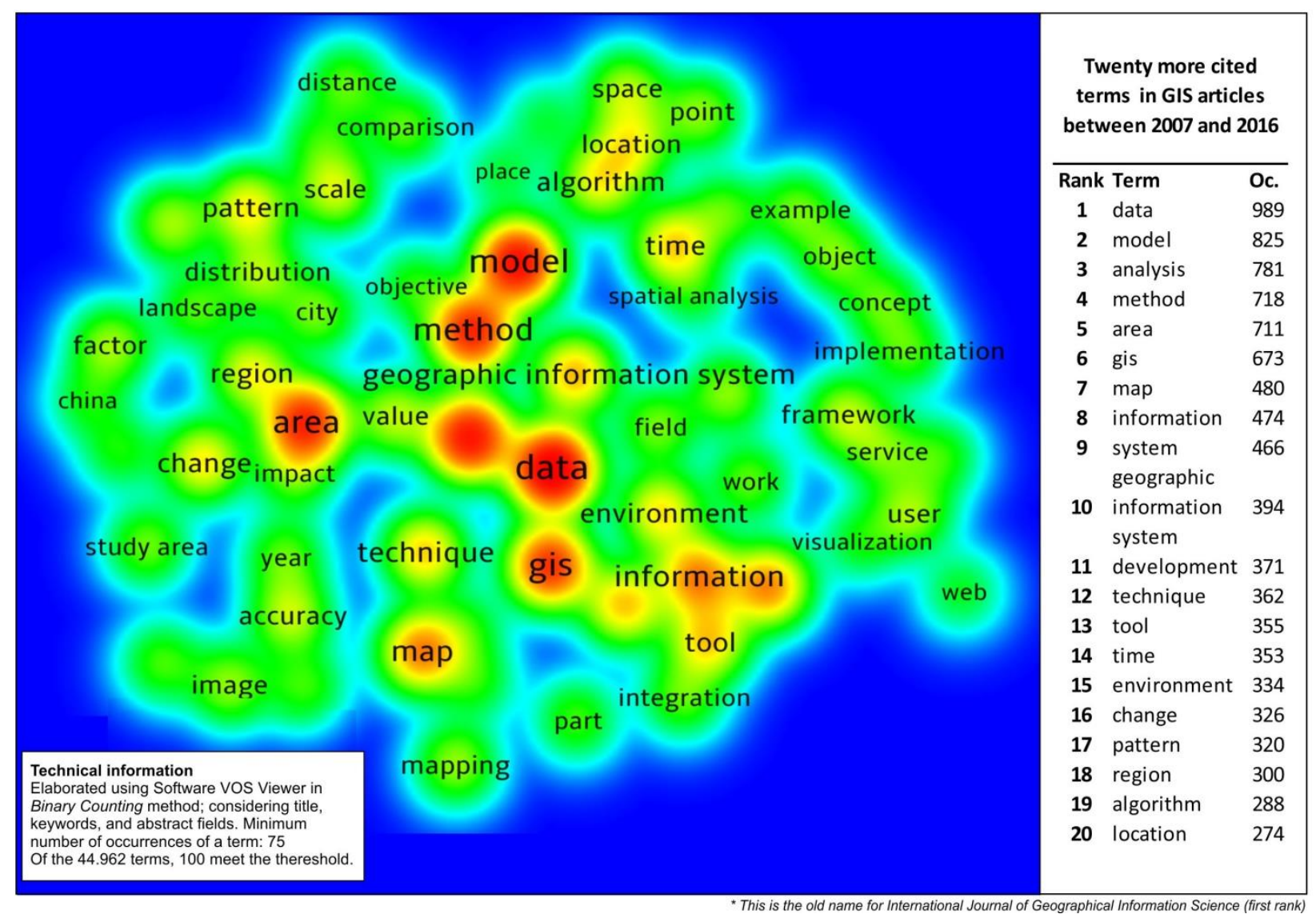

Figure 6: Most cited words in the papers (2007-2016).

The authors most cited in the retrieved papers are shown in Figure 7 and Table 2. From a temporal point of view, it can be seen that the highest concentration of documents occurred in a 15-year period (from 1990 to 2005). More papers were published in the 1990s and 2000s, and the papers published in the 1970s were not cited in later publications. Papers published after 2010 did not appear in Figure 7 because they are not quantitatively relevant.

The main characteristics of figure 7 are the selection of authors is performed by a citation score, the vertical position is defined by the year of publication and the horizontal position is determined by its relations with other publications, the curved lines represent the link between citations and the cited publication is always located above the citation publication.

The analysis of the oldest citations allowed the identification of the most relevant papers, including "A note on two problems in connection with graphs" (1959) by E. W. Dijkstra, "Fuzzy sets" (1965) by L. A. Zadeh (1965), "Innovation Diffusion as a Spatial Process" (1967) by T. Hägerstrand, and "A Computer Movie Simulating Urban Growth in the Detroit Region" (1970) by W. Tobler, and the latter author established the First Law of Geography (Tobler's Law). 


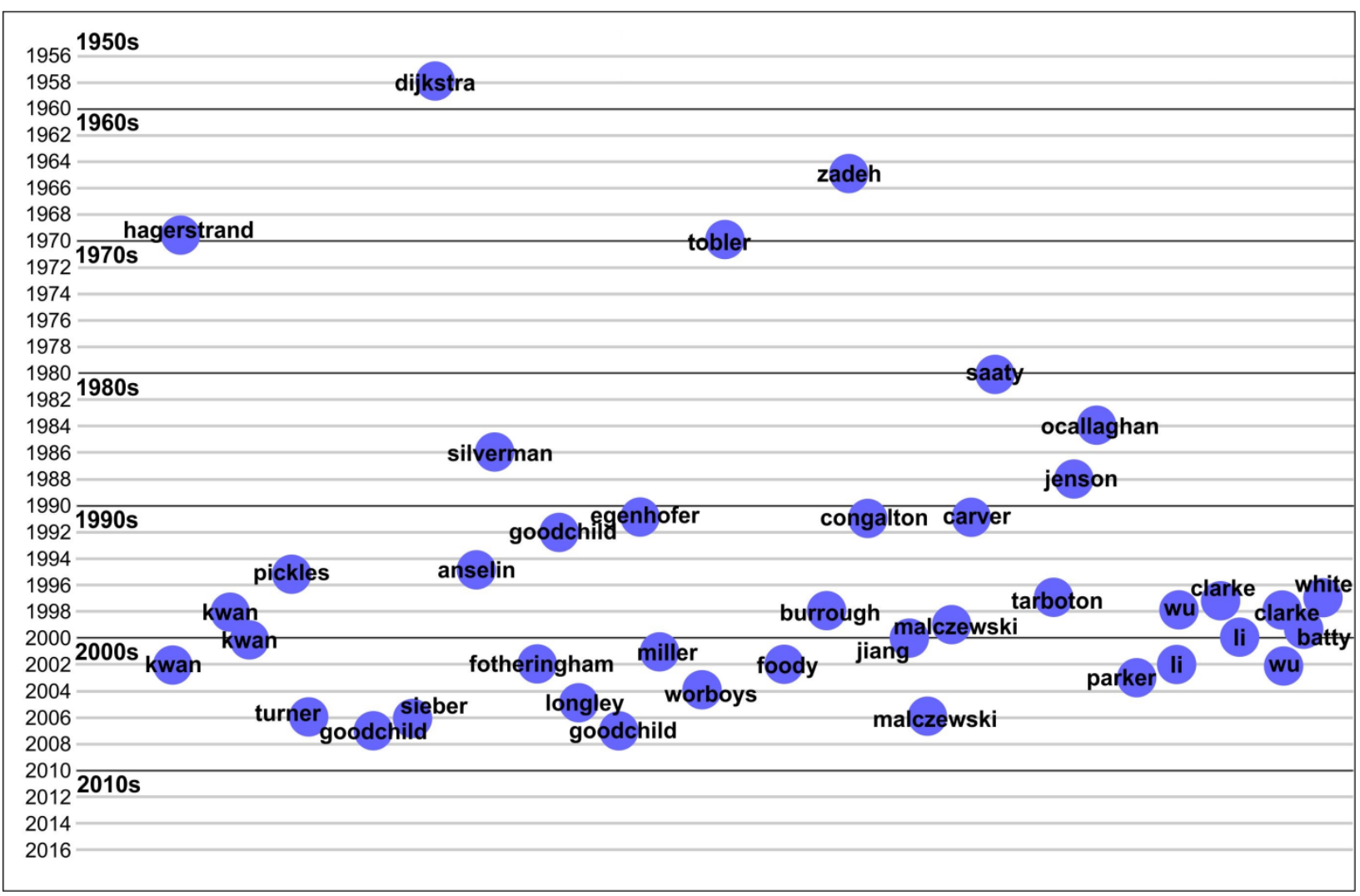

Figure 7: Temporal representation of citations in the evaluated sample (2007-2016).

The 1980s were less representative in terms of citation, but relevant in content. Some examples include Saaty in 1980 (The analytic hierarchy process), O'Callaghan and Mark in 1984 (The Extraction of Drainage Networks from Digital Elevation Data), Silver in 1986 (Density Estimation for Statistics and Data Analysis), and Jenson in 1988 (Extracting Topographic Structure from Digital Elevation Data for Geographic).

In the 1990s, several papers on cellular automata were published. Clarke (1998) reported that "they are simple models for simulating complex systems, acting in a space of action (usually a grid) using a set of conditions, rules, and initial parameters. His two papers were "A Cellular Automaton Model and GIS: Long-Term Growth Prediction for San Francisco and Washington/Baltimore" (1998) and "Self-Modifying Cellular Automaton Model of Historical Urbanization in the San Francisco Bay Area" (1997). In 1997, R. White published the paper "The Use of Constrained Cellular Automata for High-Resolution Modeling of Urban Land-Use Dynamics," and the following year, F. Wu wrote "Simulation of Land Development through the Integration of Cellular Automata and Multicriteria Evaluation." Both studies were published in Environment and Planning B.

The study "Neural-network-based cellular automata for simulating multiple land use using GIS" (2002) and "Modeling sustainable urban development by the integration of constrained cellular automata and GIS" (2000) by X. Li, and "Calibration of stochastic cellular automata: the application to rural-urban land conversions" (2002) by F. L. Wu are also among the most cited. In the decade of 2010, the number of citations did not reach the minimum to be represented in figure 7 . 
Table 2: Main publications cited in our sample (2007-2016).

\begin{tabular}{|c|c|c|c|c|c|c|}
\hline № & citations & Author & Publication Title & $\begin{array}{l}\text { Type of } \\
\text { Publication }\end{array}$ & Year, volume, and page & DOI \\
\hline 1 & 80 & $\begin{array}{l}\text { Goodchild, } \\
\text { M.F. }\end{array}$ & $\begin{array}{l}\text { Citizens as sensors: the } \\
\text { world of volunteered } \\
\text { geography }\end{array}$ & GeoJournal & 2007, v.69, p.211 & $\begin{array}{l}\text { 10.1007/s107 } \\
08-007-9111-y\end{array}$ \\
\hline 2 & 61 & Sieber, R. & $\begin{array}{l}\text { Public Participation } \\
\text { Geographic Information } \\
\text { Systems: A Literature } \\
\text { Review and Framework }\end{array}$ & $\begin{array}{l}\text { Annals of the } \\
\text { Ass. of Amer. } \\
\text { Geographers }\end{array}$ & 2006, v.96, p.491 & $\begin{array}{l}10.1068 / \mathrm{b} 240 \\
247\end{array}$ \\
\hline 3 & 56 & Malczewski, J. & $\begin{array}{l}\text { GIS and Multicriteria } \\
\text { Decision Analysis }\end{array}$ & (Book) & 1999 & $\begin{array}{l}10.1080 / 1365 \\
88102101370 \\
04\end{array}$ \\
\hline 4 & 53 & Tobler, W.R. & $\begin{array}{l}\text { A Computer Movie } \\
\text { Simulating Urban } \\
\text { Growth in the Detroit } \\
\text { Region }\end{array}$ & $\begin{array}{l}\text { Economic } \\
\text { Geography }\end{array}$ & 1970, v.46, p.234 & $\begin{array}{l}10.1080 / 1365 \\
88100240886\end{array}$ \\
\hline 5 & 52 & $L i, X$. & $\begin{array}{l}\text { Neural-network-based } \\
\text { cellular automata for } \\
\text { simulating multiple land } \\
\text { use changes using GIS }\end{array}$ & $\begin{array}{l}\text { Int. Journal of } \\
\text { Geogr. Inform. } \\
\text { Science. }\end{array}$ & 2002, v.16, p.323 & $\begin{array}{l}10.1016 / s 003 \\
4- \\
4257(01) 0029 \\
5-4\end{array}$ \\
\hline 6 & 50 & Clarke, K.C. & $\begin{array}{l}\text { Loose Coupling A } \\
\text { Cellular Automaton } \\
\text { Model and GIS: Long- } \\
\text { Term Growth } \\
\text { Prediction for San } \\
\text { Francisco and } \\
\text { Washington/Baltimore }\end{array}$ & $\begin{array}{l}\text { Int. Journal of } \\
\text { Geogr. Inform. } \\
\text { Science. }\end{array}$ & 1998, v.12, p.699 & $\begin{array}{l}10.1016 / 0034 \\
- \\
4257(91) 9004 \\
8-b\end{array}$ \\
\hline 7 & 49 & Clarke, K.C. & $\begin{array}{l}\text { A Self-Modifying } \\
\text { Cellular Automaton } \\
\text { Model of Historical } \\
\text { Urbanization in the San } \\
\text { Francisco Bay Area }\end{array}$ & $\begin{array}{l}\text { Environment } \\
\text { and Planning B }\end{array}$ & 1997, v.24, p.247 & $\begin{array}{l}10.1068 / \mathrm{b} 240 \\
323\end{array}$ \\
\hline 8 & 48 & $L i, X$. & $\begin{array}{l}\text { Modeling sustainable } \\
\text { urban development by } \\
\text { the integration of } \\
\text { constrained cellular } \\
\text { automata and GIS }\end{array}$ & $\begin{array}{l}\text { Int. Journal of } \\
\text { Geogr. Inform. } \\
\text { Science. }\end{array}$ & 2000, v.14, p.131 & $\begin{array}{l}10.1068 / \mathrm{b} 250 \\
103\end{array}$ \\
\hline 9 & 46 & Goodchil, M.F. & $\begin{array}{l}\text { Towards a general } \\
\text { theory of geographic } \\
\text { representation in GIS }\end{array}$ & $\begin{array}{l}\text { Int. Journal of } \\
\text { Geograp. } \\
\text { Inform. } \\
\text { Science. }\end{array}$ & 2007, v.21, p.239 & $\begin{array}{l}10.1080 / 1365 \\
88106006615 \\
08\end{array}$ \\
\hline 10 & 42 & Malczewski, J. & $\begin{array}{l}\text { GIS-based multicriteria } \\
\text { decision analysis: a } \\
\text { survey of the literature }\end{array}$ & $\begin{array}{l}\text { Int. Journal of } \\
\text { Geogr. Inform. } \\
\text { Science. }\end{array}$ & 2006, v.20, p.703 & $\begin{array}{l}10.1080 / 1365 \\
88106009652 \\
71\end{array}$ \\
\hline 11 & 39 & Burrough, P. A. & $\begin{array}{l}\text { Principles of } \\
\text { Geographical } \\
\text { Information Systems }\end{array}$ & (Book) & 1998 & $\begin{array}{l}10.1111 / 1467 \\
-8306.00309\end{array}$ \\
\hline
\end{tabular}


The most cited classic studies from the 1990s included "Geographical information science" (1992) by M. Goodchild, and "Integrating multi-criteria evaluation with geographical information systems" (1991) by S. J. Carver. In the 1990s, several books on GIS were published, including "Principles of Geographical Information Systems" (1998) by P. A. Burrough; "Geographical Analysis" (1995) by L. Anselin, "Ground Truth: The Social Implications of Geographic Information System" (1995) by J. Pickles, and "GIS and Multicriteria Decision Analysis" (1999) by J. Malczewski.

The sample data highlighted the importance of improving integration between GIS and users in the 2000s. Often cited publications in that period were: "Citizens as sensors: the world of volunteered geography" (2007) by M. Goodchild, and "Public Participation Geographic Information Systems: A Literature Review and Framework" (2006) by R. Sieber, and the books "Introduction to Neogeography" (2006) by A. J. Turner, and "Community Participation and Geographic Information Systems" (2002) by D. Weiner.

Another relevant line of research is the integration between GIS, remote sensing, and different land-use classification methods. The studies "Multi-Agent Systems for the Simulation of Land Use and Land Cover Change" (2003) by D. C. Parker, "Status of land cover classification accuracy assessment" (2002) by G. M. Foody, and "A review of assessing the accuracy of classification of remotely sensed data" (1991) by R. G. Congalton were the most cited from 2005 to 2016. A critical reflection on GIS and derived technologies is made in the studies "Feminist Visualization: Reenvisioning GIS as a Method in Feminist Geographic Research" (2002) by Mei-Po Kwan.

\section{Conclusions}

The bibliometric mapping of scientific papers published from 2007 to 2016 in the top 20 GIS journals extracted from the Web of Science Core Collection, allowed evaluating the characteristics and recent trends of these publications.

The most productive period was from 2012 to 2013 and publication peaks occurred in 2009 and 2012. The annual growth rate of publication in the selected journals was $1.8 \%$. The most productive areas of knowledge were Geography, Computer Science and Physical Geography. Environmental Sciences/Ecology and Engineering showed significant growth in 2014/2015. The major GIS research centers were concentrated in the northern hemisphere, with the three main clusters being North America, Western Europe, and Eastern Asia. 61.7\% of papers were published in English-speaking countries.

The Journal Geographic Information Science was considered the most important in the evaluated period, maintaining the leadership with the studies by Tian, Wen and Hong (2008) and Liu et al. (2016). The most cited words were "data," "model," "analysis," "method," "area," and "map." The most cited paper was "Geographical Information Science" (1992) by M. Goodchild (80 citations), who was also the most cited author of our sample (638 citations). The most relevant topics were cellular automata, relationship between GIS and users, integration between GIS and remote sensing, different land-use classification methods, and critical reflections on technologies and GIS. 


\section{ACKNOWLEDGMENT}

We gratefully acknowledge the financial support granted to this research by the Brazilian National Council of Scientific and Technological Development (CNPq).

\section{AUTHOR'S CONTRIBUTION}

Definition of research problem (A.V.F.M. and A.P.Q.), Literature review (A.V.F.M. and A.P.Q.), Definition of methodological procedures (A.V.F.M. and A.P.Q.), Data collection (A.V.F.M.), Data processing (A.V.F.M.), Analysis and interpretation of data (A.V.F.M. and A.P.Q.), Manuscript writing (A.V.F.M. and A.P.Q.).

\section{REFERENCES}

Bunge, W. 1961. The structure of contemporary American geographic research. The Professional Geographer, 13(3), pp. 19-23.

Burrough P. A. 1998. Principles of Geographical Information Systems. Oxford (UK): Oxford University Press.

Callon, M. Courtial, J.P., Turner, W.A. and Bauin, S. 1983. From translations to problematic networks: an introduction to co-word analysis. Social Science Information, 22(2), pp. 191-235.

Caron, C., Roche, S., Goyer, D., and Jaton, A. 2008. GIScience Journals Ranking and Evaluation: An International Delphi Study. Transactions in GIS, 12(3), pp. 293-321. DOI: http://doi.wiley.com/10.1111/j.1467-9671.2008.01106.x.

Egenhofer, M. J. et al. 2016. Contributions of GIScience over the Past Twenty Years. In: Onsrud, H.; Kuhn, W. (Eds.) Advancing Geographic Information Science: the past and next twenty years. GSDI Association Press. p. 9-34.

Gatrell, A. C. and Smith, A. 1984. Networks of relations among a set of geographical journals. The Professional Geographer, 36(3), pp. 300-307.

Getis, A. 2008. A history of the concept of spatial autocorrelation: A geographer's perspective. Geographical Analysis, 40, pp. 297-309.

Goodchild, M. F. 1992. Geographical Information Science. International journal of Geographical Information Systems, 6(1), pp.31-45. DOI: 10.1080/02693799208901893.

Goodchild, M. F., Yuan, M. and Cova, T. J. 2007. Towards a General Theory of Geographic Representation in GIS. International Journal of Geographical Information Science, 21(3), pp.23960. DOI: 10.1080/13658810600965271.

Harremoes, P. and Topsoe, F. 2005. Zipf's law, hyperbolic distributions and entropy loss. Electronic Notes in Discrete Mathematics, 21, pp.315-318. 
Huggett, S. 2013. Journal bibliometrics indicators and citation ethics: A discussion of current issues. Atherosclerosis, 230(2), p. 275-277. DOI: 10.1016/j.atherosclerosis.2013.07.051

Li, J., Liu, H., Guo, W. and Yu, A. 2016. Visual analysis based on the data of Chinese surveying and mapping journals. ISPRS Annals of Photogrammetry, Remote Sensing and Spatial Information Sciences, III(4), pp.41-48.

Li, L., Liu, Y., Zhu, H., Ying, S., Luo, Q., Luo, H., Kuai, X., Xia, H. and Shen, H. 2017. A bibliometric and visual analysis of global geo-ontology research. Computers \& Geosciences, 99, pp.1-8. DOI: 10.1016/j.cageo.2016.10.006

Liu, F., Lin, A., Wang, H., Peng, Y. and Hong, S. 2016. Global research trends of geographical information system from 1961 to 2010: a bibliometric analysis. Scientometrics, 106, pp.751-768. DOI: 10.1007/s11192-015-1789-x

Morris, S. A. and Martens, V. D. V. 2009. Mapping Research Specialties. Annual Review of Information Science and Technology, 42(1), pp.213-95. DOI: 10.1002/aris.2008.1440420113.

Peng, Z.R. and Tsou, M.H. 2003. Internet GIS: Distributed Geographic Information Services for the Internet and Wireless Networks. United States: John Wiley \& Sons.

Pritchard, A. 1969. Statistical Bibliography or Bibliometrics? Journal of Documentation, 25(4), pp.348-49.

Robinson, W. C. and Poston, P. E. 2006. Literature Use by Geography Scholars. Scholars, Behavioral \& Social Sciences Librarian, 25(1), pp.13-31. DOI: 10.1300/J103v25n01_02.

Scarletto, E. A. Mapping the Literature of GIS. 2014. College \& Research Libraries, 75(2), pp.179201. DOI: $10.5860 / \mathrm{crl} 12-389$.

Small, H. 1997. Update on Science Mapping: Creating Large Document Spaces. Scientometrics, 38(2), pp.275-93. DOI: 10.1007/BF02457414.

Stoddart, D.R. 1967. Growth and Structure of Geography. Transactions of the Institute of British Geographers, 41, pp.1-19.

Tian, Y., Wen, C. and Hong, S. 2008. Global scientific production on GIS research by bibliometric analysis from 1997 to 2006. Journal of Informetrics, 2, pp.65-74. DOI: 10.1016/j.joi.2007.10.001.

van Eck, N. J. 2011. Methodological Advances in Bibliometric Mapping of Science. PhD. Rotterdam: Erasmus University.

van Eck N.J. and Waltman L. 2007. VOS: A New Method for Visualizing Similarities Between Objects. In: Decker R., Lenz H.J. (eds) Advances in Data Analysis. Studies in Classification, Data Analysis, and Knowledge Organization. Berlin, Heidelberg

van Eck, N. J., Waltman, L., Dekker, R. and van den Berg, J. 2010. A comparison of two techniques for bibliometric mapping: Multidimensional scaling and VOS. Journal of the Association for Information Science and Technology, 61, pp.2405-2416. DOI:10.1002/asi.21421

van Eck, N. J. and Waltman, L. 2010. Software survey: VOSviewer, a computer program for bibliometric mapping. Scientometrics, 84(2), p. 523-538. DOI: 10.1007/s11192-009-0146-3

van Eck, N. J. and Waltman, L. 2014. CitNetExplorer: A new software tool for analyzing and visualizing citation networks. Journal of Informetrics, 8(4), p. 802-823. DOI: 10.1016/j.joi.2014.07.006 
Waltman, L., van Eck, N. J. and Noyons, E. C. M. 2010. A Unified Approach to Mapping and Clustering of Bibliometric Networks. Computer Sciences. Available at: <http://www.mod.gov.uk/en/Publications/PublicationsPolicyAndGuidance/MOD_085307>[Acces sed 17 June 2019]. DOI: http://arxiv.org/abs/1006.1032.

Wei, F., Grubesic, T. H. and Bishop, B. W. 2015. Exploring the GIS Knowledge Domain Using Citespace, The Professional Geographer, 67(3), pp.374-384. DOI: 10.1080/00330124.2014.983588.

Whitehand, J. W. R. 1984. The Impact of Geographical Journals: A look at the ISI Data. Area, 16(2), pp. 185-187.

Wrigley, N. and Matthews, S. 1986. Citation Classics and Citation Levels in Geography. Area, 18(3), pp. 185-194.

Xuemei, W., Mingguo, M., Xin, L. and Zhiqiang, Z. 2014. Applications and Researches of Geographic Information System Technologies in Bibliometrics. Earth Science Informatics, 7(3), pp.147-52. DOI:10.1007/s12145-013-0132-4. 